Increases in yield from 10 to 40 per cent are claimed. These and other contributions from the U.S.S.R. to the understanding of the reactions of plants to water and to heat were discussed by N. S. Petinov and P. A. Genkel.

The discussions will be published in two parts: (1) Reviews of research prepared as background material on "The Income and Loss of Water" (F. L. Milthorpe), "Soil Water Relations" (W. R. Gardner), "Physiological and Morphological Changes in Plants due to Water Deficiency" (O. Stocker), "Adaptation to Drought-Xerophytism" (H. R. Oppenheimer), "Methods of Research on Water Relations" (F.
Eckardt), "The Management of Native Vegetation" (R. M. Moore), "Principles of Dry Land Crop Management" (S. A. Taylor), "Significance of Fallow as a Management Technique" (W. J. Staple), "Principles of Irrigated Cropping" (R. M. Hagan and Y. Vaadia), "Survey of Research on the Water Regimes of Plants" (P. A. Genkel and K. A. Bodanova), "The Water Regime of Plants on Saline Soils" (B. P. Strogonov); (2) Proceedings of the symposium, which include about forty papers contributed on detailed aspects within the above fields by workers from seventeon different countries.

F. L. Milthorpe

\title{
MINING GEOPHYSICS
}

$\mathrm{T}$ HE second Nordic Meeting for Mining Geophysics was held at Haandværkerforeningen, Copenhagen, during December 7-8. More than fifty geophysicists and technicians, including five from Finland, eleven from Norway, and eighteen from Sweden, attended. The sessions were presided over by Haakon Brækken from Trondheim, Norway, chairman of the planning committeo.

The technical programme included twelve papers, two of which were concerned with Greenland. B. Sjögren (Sweden) reported on a seismic refraction and reflexion investigation on the Malmberget glaciers. The area survoyed lies about $20 \mathrm{~km}$. south-east of Mestersvig, Kong Oscars Fjord, east Greenland, and the purpose of the survey was to determine the thickness of the ice-moraine layer of the glaciers. The bed-rock is mainly sandstone from the Carboniferous period which is superseded by tertiary granite. The bed-rock velocities measured varied from 4,800 to $5,400 \mathrm{~m}$. per sec. while the longitudinal wave velocity in the ice-moraine layer was between 3,700 and $3,800 \mathrm{~m}$. $/ \mathrm{sec}$. ; the transverse wave velocity in this layer was of the order of 1,600 $1,700 \mathrm{~m}$./sec. The measured thickness of the icemoraine cover varied from 120 to $450 \mathrm{~m}$. The bedrock under the glaciers was discovered to be U-dale shaped with relatively shallow slopes while the rock walls on the sides of the glaciers climbed very steoply to about $700 \mathrm{~m}$. above the glacier surface. The second paper dealing with Greenland, "A Study of the Disturbances due to Salt-water on Minor Loopframe Indications", was presented by J. Bondam (Denmark). The survey is part of experimental measurements carried out near Narssaq, south-wost Greenland.

The important problem of the elucidation of structure was illustrated by G. F'. Sakshaug (Norway). Electromagnetic, magnetic, and self-potential surveys have been employed in the exploration of copper mineralization at Bidjovagge, Finmark (Northern Norway). Electromagnetic surveys have been conducted as a general reconnaissance method as well as towards the examination of detail. Electromagnetic anomalies are largely confined to beds of graphite shalo occurring in the area. Magnetic surveys define magnetite-bearing greenstones. Selfpotential surveys give essentially a map of the graphite shale under the moraine cover. All three methods have been essential to the interpretation of the structural relations in the area. Irrogularities in the anomalics reflect tectonic disturbances, and ore-mineralizations-as diamond drilling has con- firmed-are related to areas of intense disturbance. Another example of structure mapping was given by $V$. Münther (Denmark) in a presentation of a magnetic survey of Bornholm and its application to the geology, especially the tectonics. The island has been covered by magnetic stations in squares, the side-length being 500 metres. Moreover, a considerable number of traverses has been established, stations distances being from 10 to $20 \mathrm{~m}$. apart. It has in this way been possible to correct the previous boundary lines between granite and sandstone. Known faults have beon traced in more detail and older faults have been shown. In the granitic area the magnetic contours indicate the granite variety. Interpretation of the anomaly map indicated partly stronger magnetic layers at a greater depth, partly a change in the magnetic field with time. The practical aspect of the survey is the economic interest in sandstone.

A case-history was demonstrated by J. Esporsen (Sweden). Magnetic and gravimetric measurements have pointed out the existence of two important and several minor ore bodies at Svappavaary near Kiruna, north Sweden. The applicability of magnetometers and gravimeters in ore prospecting is underlined by the confirming drilling results. $J$. Nuutilainen (Finland) described gravimetric application in ore prospecting. Levelling is carried out by means of a mercury pressure-gange and a water tube which at the same time is the measuring tape. $H$. Paarma (Finland) considered magnetic gradient measurements with regard to ore bodies and structures. A report of interest concerning the conductivity of magnetite, sulphide, and different rocks sampled in Swedish mines was given by Sture Werner (Sweden). Measurements were undertaken in fifteen sulphide-mines and twenty iron-mines. The resistivity, which is the reciprocal of the conductivity, was found to amount to $300,000-3,000,000$ ohm$\mathrm{cm}$. for the eircumjacent rocks, while the value for magnetite and sulphide was usually found to be of the order $0.01 \mathrm{ohm}-\mathrm{cm}$. The resistivity increases rapidly as the percentage of magnetite decreases; for example, an ore sample with 50 per cent iron has a resistivity of about 10,000 ohm-cm. For the sulphide samples the resistivity increases slowly as the percentage of sulphide decreases. Only at a very low sulphide content do the resistivity values rise.

A new instrument for measuring the curvature in boro-holes was presented by A. Holm (Sweden), and A. Breen (Norway) discussed the employment of phase-sensitive voltmetors in mcasuring electromagnetic fields. A point of practical importance was 
reported by B. Karlemo (Sweden) in a description of methods for production of geophysical maps.

At a joint evening meeting with the Danish Geophysical Society, D. Malmqvist (Sweden) gave a review of electrochemical ore-prospecting methods and emphasized the utility of this prospecting method. The 'polarization provoquée' method proposed by Schlumberger about forty years ago seems to be very suitable, especially in cases dealing with disseminated ores, and Mr. Malmqvist demonstrated some survey examples from northern Sweden.

The chairman, H. Brækken (Norway), introduced at the business meeting the very important problem of education of mining geophysicists. The meeting appointed a committee (Brækken, Werner and
Tengstrøm (Sweden)) to consider the different points and to report at the next meeting.

With regard to the planning committee for the third meeting, which is contemplated within two years, the meeting appointed B. Tornqvist as chairman (Sweden), and H. Brækken, M. Puranen (Finland), and S. Saxov (Denmark) as members.

In all, the second Nordic Meeting for Mining Geophysics proved to be most successful, the attendance being about 100 per cent higher than at the first meeting at Boliden, Sweden, during November $7-9,1956$; the discussions were many and the opinion of the meeting strongly supported the arrangements for future meetings and co-operation in common problems.

SVEND SAXOV

\section{THE MEDICAL RESEARCH COUNCIL}

\section{REPORT FOR THE YEAR 1957-58}

\begin{abstract}
$\mathrm{T}$ HE recent report of the Medical Research Council for the year 1957-58, prepared by the Committee of Privy Council for Medical Research, adopts once more the form now used for several years (Cmnd. 792. Pp. viii +288. (London: H.M. Stationery Office, 1959.) 13s. net). Instead, that is to say, of giving detailed accounts of all the researches in progress, it gives articles based on certain aspects of the Council's very varied programme, the intention being to deal, once every few years, with all the important fields of research undertaken by the Council's staff. These articles are also published separately under the title "Current Medical Research" (Pp. iii +46. (London : H.M. Stationery Office, 1959.) 3s. 6d. net).

In this publication and also in the report itself we are given a description of the Council's Laboratory in Gambia, West Africa. As part of its contribution to research in tropical medicine, the Council maintains three laboratories, in Uganda, Jamaica and Gambia, respectively, and that in Gambia here described is the oldest and largest. Unlike the others, it is self-contained and is not attached to any local institution. Situated at Fajara, it was originally part of the Council's Human Nutrition Research Unit in London, but its scope has now been widened to include research, not necessarily on tropical medicine, but in other fields as well. Many research workers use its increased facilities-cardiologists, chest and other specialists, pædiatricians, public health workers and others. The centre is visited by many research workers from Britain and has lately been used by a team representing the Council's Research Group on trachoma, a cause of blindness which, because of the menace it is, is
\end{abstract}

engaging the attention of research workers all over the world. This centre is also developing research on the hyperendemic malaria of the Gambia region, a region which offers special facilities for work of this kind, and this is discussed in a separate article in the report. Much of it is done at Keneba, and to facilitate communication between Keneba and the laboratories at Fajara a radio-telephone has been set up, and the Wellcome Trust has generously provided a cabincruiser, The Lady Dale, which can also be used as a floating laboratory.

As well as the article just mentioned on the hyperendemic malaria of the Gambia area, the report includes articles on the remarkable work being done by members of the Council's staff on intracellular organelles and on the enzymes contained in them. Other articles discuss the work being carried out on the viruses of trachoma and inclusion blenorrhœea, the types of the bacillus that causes Sonne dysentery, the cancer-producing viruses and their immunology, the ultra-microscopic analysis of body fluids, the performance of coal miners in hot atmospheres, the fertilization of the mammalian egg and the rehabilitation of schizophrenic people. Another article of interest discusses research in general medical practice, a line of work which is much to be encouraged. An innovation in the report is the introduction of two photographs, one of which shows The Lady Dale, and two line illustrations.

For the rest the report contains its usual features. Brief summaries of the work of each of the Council's research units are given, together with the names and. research addresses of the Council's many workers. A long bibliography lists the varied work that these workers have published.

G. LAPAGE

\section{COMPARISON OF RAIN-GAUGES}

$\mathrm{T}$ HE measurement of precipitation is a difficult problem because of the great variations in the nature of the precipitation and of the effects of wind eddies around the gauge. The radii of liquid drops and their rates of fall range from $0.2 \mathrm{~mm}$. at $0.7 \mathrm{~m}$. $/ \mathrm{sec}$. of drizzle to $5 \mathrm{~mm}$. at $8 \mathrm{~m}$. $/ \mathrm{sec}$. of the heaviest thunderstorm rain, while the speed of the wind around the gauge can vary over a somewhat greater range. Solid precipitation is even more difficult to measure. It ranges from fine snow to heavy fast-falling hail-stones and may at low temperatures completely choke the gauge if, as is usual, no heating 